\title{
In-vitro Gastric acid percent neutralizing potential of household remedies verses marketed antacid preparation: A case report
}

\author{
Balu S. Khandare*, Sandip S. Kshirsagar and Nikhil S. Bhujbal \\ Kasturi Shikshan Sanstha College of Pharmacy Shikrapur Pune, Maharashtra, India-412208
}

\begin{abstract}
Gastric acidity is a very common condition among the peoples of developing and developed countries. Increased gastric pH is associated with gastric ulceration, Bleeding ulcers, GERD, heartburn, discomfort, nausea and vomiting. The instant and quick relief from acidity can be obtained by oral administration of antacids. Current study was carried out to determine the acid neutralizing effect of household remedies like cold milk, Baking soda, Baking soda + citric acid in water verses marked preparations like Effervescent granules (ENO, Digene) and liquid antacid Gelusil $(5 \mathrm{ml}$ and $10 \mathrm{ml})$. Gastric simulation fluid of $\mathrm{pH} 1.2$ was prepared and $\mathrm{pH}$ was recorded before and after addition of marketed antacid/ household remedies. Observations were recorded in multiple of three for 0 min to $60 \mathrm{~min}$. percent acid neutralization were calculated for each mar keted/ household preparation. Results advocate that baking soda in water and Gelusil $10 \mathrm{ml}$ shows significant percent acid neutralization $444.35 \%$ and $428.57 \%$ respectively. The effect of acid neutralization of baking soda in water was instant and remained same whereas Gelusil $10 \mathrm{ml}$ showed progressive acid neutralization over a period of time. Effervescent granules ENO and Digene showed 322.58303.14\% acid neutralization respectively. Milk 259.67\% Gelusil188.28\% and Baking soda + citric acidin Water421.25\% showed acid neutralization. From results it can be concluded that household remedies are also significantly effective to control the acidity.
\end{abstract}

Keywords: Antacid, Effervescent granules, Milk, Baking soda. \% acid neutralization.

Article Info: Received 19 June 2019; Review Completed 23 July 2019; $\quad$ Accepted 29 July 2019; Available online 15 August 2019

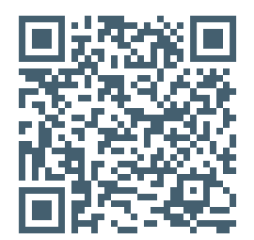

\section{Cite this article as:}

Khandare BS, Kshirsagar SS, Bhujbal NS, In-vitro Gastric acid percent neutralizing potential of household remedies verses marketed antacid preparation: A case report, Journal of Drug Delivery and Therapeutics. 2019; 9(4-s):595-597 http://dx.doi.org/10.22270/jddt.v9i4-s.3271

Balu S. Khandare, Kasturi Shikshan Sanstha College of Pharmacy Shikrapur Pune, Maharashtra,India-412208

\section{INTRODUCTION:}

Increase gastric $\mathrm{pH}$ is very common condition among the children's, Younger's, adults and old age persons. Many causative reasons contributes to increase the acidity like Modern life style, Drugs, Smoking, alcohol addiction, spicy food, stressful conditions, inadequate sleep, chewing tobacco, beverages etc. acidity can be controlled by minimizing above causative factors. In certain unavoidable conditions like stressful work, work in night shift or daily dose of medication acidity must be controlled by drug treatment.

Continuous increase in gastric $\mathrm{pH}$ and lack of treatment leads to severe complications like heart burn, gastric and duodenal ulcer, GI bleeding and GERD. Instant and quick relieve can be given by oral administration of acid neutralizing agents and prophylaxis treatment with ulcer healing drugs.

Antacids are alkaline that are used as acid-neutralizing agents for protection against stomach acidity related disorders. It is an inexpensive and safe over-the-counter (OTC) medication that is available in tablet, effervescent granules or suspension form. It can neutralize the gastric acid fairly rapidly and is often used for immediate symptomatic relief. Certainly the carbonate antacids (sodium bicarbonate and calcium carbonate) can cause excessive belching, nausea, abdominal distention, and flatulence. These antacids when used in high doses or in patient with kidney failure may result in metabolic alkalosis. Magnesium and aluminum salts due to the opposite effects in may have increase bowel movement. Whereas aluminum salts may result in constipation, magnesium can lead to diarrhea.

Various home remedies are available to overcome the effect of antacid and successfully control the acidity. Among them cold milk and spoon of baking soda are very common. Current study was conducted to screen the acid neutralizing effect of home remedies against marketed acid neutralizing preparations.

\section{Objective:}

Objective of current studies are:

1. To screen the In vitro acid neutralizing potential of household remedies verses marketed antacid preparation. 
2. To screen the percentage acid neutralization and duration of action.

\section{EXPERIMENTAL METHOD:}

\section{Preparation of Gastric simulation fluid:}

Gastric simulation fluid is prepared by adding $2 \mathrm{gm}$ of $\mathrm{NaCl}+$ $7 \mathrm{Ml} \mathrm{HCl}+3.2 \mathrm{gm}$ of purified pepsin and volume is making up to $1000 \mathrm{Ml}$ of deionized water. PH of GSF is 1.2 .

\section{Screening of acid neutralizing effect}

\section{For Marketed preparation:}

\section{a. Effervescent Granules:}

Two common marketed preparations of Effervescent Granules (ENO and Gasofast) were added in $200 \mathrm{ml}$ of drinking water. Prepared antacid solution was added in 200 ml GSF. pH was recorded before and after addition of antacid solution. Change in $\mathrm{pH}$ was recorded after every $10 \mathrm{~min}$ for next 1 hour.

\section{b. Antacid suspension:}

Antacid suspension (Gelosile) $5 \mathrm{ml}$ and $10 \mathrm{ml}$ was added in $200 \mathrm{ml}$ GSF. pH was recorded before and after addition of antacid solution. Change in $\mathrm{pH}$ was recorded after every 10 min for next 1 hour.

\section{For Household remedies:}

\section{a. Cold Milk:}

Cold milk 200m was added in $200 \mathrm{Ml} \mathrm{GSF}$. pH was recorded before and after addition of antacid solution. Change in $\mathrm{pH}$ was recorded after every 10 min for next 1 hour.

\section{b. Baking Soda:}

2gm of baking soda with and without citric acid was added in $200 \mathrm{ml}$ drinking water. Prepared solutions were added 200 $\mathrm{ml} \mathrm{GSF}$. pH was recorded before and after addition of antacid solution. Change in $\mathrm{pH}$ was recorded after every $10 \mathrm{~min}$ for next 1 hour.

Percentage inhibition was calculated by change in $\mathrm{pH}$ before and after addition of respective antacid.

\section{RESULT AND DISCUSSION:}

Percent Acid neutralizing effect of Marketed preparation verses Home remedies

\begin{tabular}{|c|c|c|c|c|c|c|c|c|}
\hline $\begin{array}{l}\text { Marketed } \\
\text { Preparation }\end{array}$ & $\begin{array}{l}\text { Initial pH } \\
\text { of GSF }\end{array}$ & $\begin{array}{l}\text { GSF pH } \\
\text { after } \\
\text { Addition }\end{array}$ & $\begin{array}{l}\text { After } 10 \\
\text { Min }\end{array}$ & $\begin{array}{l}\text { After } 20 \\
\text { Min }\end{array}$ & $\begin{array}{l}\text { After } 30 \\
\text { Min }\end{array}$ & $\begin{array}{l}\text { After } 40 \\
\text { Min }\end{array}$ & $\begin{array}{l}\text { After } 50 \\
\text { Min }\end{array}$ & $\begin{array}{l}\text { After } 60 \\
\text { Min }\end{array}$ \\
\hline \multicolumn{9}{|c|}{ ENO( ENO sachet of $6 \mathrm{gm}$ added in $200 \mathrm{ml}$ water $+\mathrm{GSF}$ ) } \\
\hline Mean & 1.24 & 5.18 & 5.20 & 5.23 & 5.23 & 5.24 & 5.24 & 5.24 \\
\hline $\begin{array}{l}\% \text { Acid } \\
\text { neutralization }\end{array}$ & $\begin{array}{ll}----- \\
\end{array}$ & 317.74 & 319.35 & 321.77 & 321.77 & 322.58 & 322.58 & 322.58 \\
\hline \multicolumn{9}{|c|}{ Digene( Digene sachet of 6gm added in $200 \mathrm{ml}$ water + GSF) } \\
\hline Mean & 1.27 & 5.01 & 5.05 & 5.07 & 5.07 & 5.04 & 5.06 & 5.12 \\
\hline $\begin{array}{l}\% \text { Acid } \\
\text { neutralization }\end{array}$ & ------ & 294.48 & 397.63 & 299.21 & 299.21 & 296.85 & 298.42 & 303.14 \\
\hline \multicolumn{9}{|c|}{ Gelusill 5mL( Gelusil 5ml Added in 200ml water + GSF) } \\
\hline Mean & 1.28 & 1.34 & 2.30 & 2.73 & 3.06 & 3.27 & 3.40 & 3.69 \\
\hline $\begin{array}{l}\% \text { Acid } \\
\text { neutralization }\end{array}$ & ------ & 34 & 79.68 & 113.28 & 139.06 & 155.46 & 165.62 & 188.28 \\
\hline \multicolumn{9}{|c|}{ Gelusill 10Ml( Gelusil10ml Added in 200ml water + GSF) } \\
\hline Mean & 1.26 & 6.15 & 6.23 & 6.43 & 6.48 & 6.58 & 6.63 & 6.66 \\
\hline $\begin{array}{l}\% \\
\text { neutralization }\end{array}$ & $\begin{array}{ll}------ \\
\end{array}$ & 388.09 & 394.44 & 410.31 & 414.28 & 422.22 & 426.19 & 428.57 \\
\hline \multicolumn{9}{|c|}{ Cold Milk( $200 \mathrm{ml}$ cold milk $+200 \mathrm{ml}$ GSF) } \\
\hline Mean & 1.24 & 4.41 & 4.29 & 4.35 & 4.40 & 4.64 & 4.78 & 4.46 \\
\hline $\begin{array}{l}\% \text { Acid } \\
\text { neutralization }\end{array}$ & ------ & 255.64 & 245.96 & 250.80 & 254.83 & 274.19 & 285.48 & 259.67 \\
\hline \multicolumn{9}{|c|}{ Baking soda in Water( $2 \mathrm{gm}$ baking soda added in $200 \mathrm{ml}$ water $+200 \mathrm{ml}$ GSF) } \\
\hline Mean & 1.24 & 6.69 & 6.66 & 6.67 & 6.68 & 6.69 & 6.72 & 6.75 \\
\hline $\begin{array}{l}\% \text { Acid } \\
\text { neutralization }\end{array}$ & ------ & 439.51 & 437.09 & 437.90 & 438.70 & 461.29 & 441.93 & 444.35 \\
\hline \multicolumn{9}{|c|}{ Baking soda + citric acid in Water ( $2 \mathrm{gm}$ baking soda $+2 \mathrm{ml}$ citric acid added in $200 \mathrm{ml}$ water + 200ml GSF) } \\
\hline Mean & 1.27 & 6.49 & 6.55 & 6.58 & 6.59 & 6.60 & 6.61 & 6.62 \\
\hline $\begin{array}{l}\% \text { Acid } \\
\text { neutralization }\end{array}$ & ------ & 411.02 & 415.74 & 418.11 & 418.89 & 419.68 & 426.47 & 421.25 \\
\hline
\end{tabular}

\section{CONCLUSION:}

From current study it can be concluded that household remedies like cold milk, baking soda in water and baking soda + citric acid in water have significant potential to control and neutralize acidity. In certain liver and kidney disease effervescent granules are contra-indicated where household remedies will be able to implement. Also household remedies are cheap and cost effective as compared to marketed antacid preparations. 


\section{REFERENCES}

1. In Vivo and in Vitro Evaluation of Liquid Antacids John S. Fordtran, M.D., Stephen G. Morawski, B.A., and Charles T. Richardson, M.D. N Engl J Med 1973; 288:923-928May 3, 1973.

2. Assessment of in vitro Antacid Activity of Different Root Extracts of Tephrosiapurpurea (L) Pers by Modified Artificial Stomach Model Sandhya S, VenkataRamana K, Vinod K R, ChaitanyaRsnakk.Asian Pacific Journal of Tropical Biomedicine (2012)S1487-S1492.

3.Functional gastroduodenal disorders. Talley, N.J., Stanghellini, V., Heading, R.C., Koch, K.L., Malagelada, J.R. and Tytgat, G.N.J., 1999, Gut, 45(suppl 2), pp.II37-II42.

4.Recent advances in proton pump inhibitors and management of acid-peptic disorders,Jain, K.S., Shah, A.K., Bariwal, J., Shelke, S.M., Kale, A.P., Jagtap, J.R. and Bhosale, A.V., Bioorganic \& medicinal chemistry, 2007. 15(3), pp.1181-1205.

5. Coping with common gastrointestinal symptoms in the community: a global perspective on heartburn, constipation, bloating, and abdominal pain/discomfort ,Hunt, R., Quigley, E., Abbas, Z., Eliakim, A., Emmanuel, A., Goh, K.L., Guarner, F.,
Katelaris, P., Smout, A., Umar, M. and Whorwell, P., 2014. Journal of clinical gastroenterology, May 2013. 48(7), pp.567-578.

6. Novel therapeutic strategies in acid-related disorders,Tonini, M. De Giorgio, R. and De Ponti, F., 2003. Expert Opinion on Therapeutic Patents, 13(5), pp.639-649.

7. Gastroesophageal reflux disease,Anderson, K., 2010. Radiologic technology, 81(3), pp.251-268.

8. The Doctor's Guide to Gastrointestinal Health: Preventing and Treating Acid Reflux, Ulcers, Irritable Bowel Syndrome, Diverticulitis, Celiac Disease, Colon Cancer, Pancreatitis, Cirrhosis, Hernias and More.Miskovitz, P. and Betancourt, M., 2010. John Wiley \& Sons.

9. Gastrointestinal tract. Pediatric sonography,Siegel, M.J., 2002., 4, pp.339-83.

10. The stomach and duodenum. First principles of gastroenterology: the basis of disease and an approach to management,Salena, B.J., Hunt, R.H., Sagar, M., Padol, I., Armstrong, D., Moayyedi, P., Yuan, C. and Marshall, J., 1994. 